\title{
Identity Politic Contestation in the Public Sphere: A Steep Road of Democracy in Indonesia
}

\author{
Ansar Suherman ${ }^{1 *}$, Muhammad Rizal Ardiansah Putra ${ }^{1}$, Mansur $^{2}$ \\ ${ }^{1}$ Department of Communication Science, Universitas Muhammadiyah Buton, Baubau, Indonesia \\ ${ }^{2}$ Department of Governmental Science, Universitas Muhammadiyah Buton, Baubau, Indonesia \\ *Corresponding author. Email: ansar.suherman@umbuton.ac.id
}

\begin{abstract}
This article aims to analyse and describe efforts to exploit public sphere by political elites in Indonesia through the use of mass media by spreading identity political propaganda, and efforts to find the agendasetting of the mass media, especially behind the rampant loading of news about identity politics. The results show, first, that identity politics is considered as a powerful weapon by political elites to bring down the popularity and electability of their political rivals or efforts to gain political support from the public. The issue of ethnicity and religion are two things that are always included in the political agenda of the identity of the elite in Indonesia, especially the condition of Indonesian society where the atmosphere of primordialism and sectarianism is still strong enough so that it is very easy to win public sympathy, ignite anger and sentiment of the masses by propagating ethnic issues and religion. However, the results of the DKI Jakarta governor election in 2018 and the presidential election in 2019 which were enlivened by the use of identity politics did not influence the increase in voter support. Identity politics only strengthens a small number of swing voters who have not yet determined their political choices, whereas most voters have political preferences about their respective candidates. Second, the political elite has succeeded in making the issue of identity politics into the public sphere which is supposed to be free of ethnic, religious and racial nuances. The media which should be a gatekeeper does not perform this function properly because there is no process of filtering information including the use of social media in spreading the propaganda of identity politics which further exacerbates the conflict.
\end{abstract}

Keywords: contestation, identity politics, public sphere, democracy

\section{INTRODUCTION}

The long history of democracy in Indonesia began before the independence of this republic which is full of important notes to be remembered and not to be repeated. These records can be used as lessons for future generations for the advancement of democratic civilization in this country, such as strengthening the identity politics of certain ethnic groups and political parties[1], authoritarian regime in the ruling, the use of repressive military forces to secure economic resources and political interests, as well as the hegemony of power in a political party power [2], is an experience that has occurred in Indonesia when the New Order regime was in power for more than 33 years (from 1965 to 1998). Even according to Boileau (1983), the hegemony of the Golongan Karya (Golkar) as a political party was strengthened by the new order regime by issuing Minister of Home Affairs Regulation No. 12/1969 and PP No. 6/1970, which contained a ban on Civil Servants from becoming administrators of Political Parties and may only support Golongan karya.

In 1998, the rolling of the reform era as a new era for the people of Indonesia in democracy, grew after the New Order regime was overthrown by the consolidation forces of the opposition movement which continued to be repressive [3], the rebellion of student groups[4] and the strength of the mass of the people consisting unity of people from all sectors. The reform era then became a new hope for the people of Indonesia to create a more developed and just atmosphere of democracy.

At present, after 21 years since the "reform event" took place, the state of Indonesian democracy is not so much different from before. The use of sectarianism, ethnicity, religion and race jargons is even more contrasting. The jargon wrapped up in an identity politics which causes the democratic transition to not run perfectly. In fact, by the political elite, this identity politics is increasingly maturing itself through the use of mass media (mainstream and new media) which increasingly grew after the New Order.

According to Oktavianti[5], the condition of the press in the reform era is very much different from in the New Order era. The press in the new order era was entirely under the control of the regime, while the press in the reform era was controlled by the dominance of media owners. Although media owners not only prioritize their business interests, the interests of the authorities are the main concern[6].

The increasingly crowded identity politics in the mass media in Indonesia by political elites is inseparable from the condition of this country's pluralism which has hundreds of different ethnic and regional languages, religious adherents, and races. This pluralism was then used by political elites as the main material of the campaign and its propaganda to win the sympathy and support of the people, even ways to 
maintain their political power. By highlighting identity politics, according to Unsworth that identity politics largely determine a person's attitudes and beliefs[7].

Identity politics itself is part of a social movement that occurs in society in response to the economic and political situation in the country that aims to get recognition from other groups. In the study of political science, identity politics is a new thing and is still a debate to find formula information about the definition of identity politics, although in the philosophical world the term political identity has long been a discourse. The role of identity politics according to Chen is very important in encouraging someone in making political decisions and political behavior[8].

The phenomenon of identity politics in the Indonesian public sphere became a "boom" in 2017 during the election of the Governor of Daerah Khusus Ibukota (DKI) Jakarta (Pilkada DKI Jakarta). Basuki Tjahaja Purnama alias Ahok was involved in the blasphemy issue because his words were considered to be insulting and insulting verses in the Al Quran holy book of Muslims (the case of surah al Maidah verse 51). As a result, there were several months of protests, both from groups of people on behalf of Islamic defenders and political elites along with the political parties that became Ahok's opposition in the governor's election. According to Muhtadi, Ahok who opened the Pandora's box due to his controversial speech, basically his political opponents had recognized the greatness of Ahok's performance but it was difficult for them to accept the fact. The hidden reason for rejecting Ahok is because Ahok is considered as a representation of minority groups both religious and ethnic - Christian and Chinese, by Christoffanini termed as a "representation of others"[9].

The main purpose of identity politics is not really to create divisions. Disunity is only a side goal[10], that there is a greater purpose hidden behind the politics of identity and the use of ethnicity issues is often used as the center of identity politics movements. The use of ethnicity issues is the easiest and most often used by elites to bring up emotional behavior and sentiments in a plural society like Indonesia. People will be easily provoked and dare to act anarchist when it comes to ethnicity and religious issues. This article will analyze the agenda of media settings related to the phenomenon of identity politics in the Indonesian public sphere recorded in the news in the online mass media, and see how the public response to several issues highlighted by the media.

\section{METHOD}

This research was a descriptive study with a qualitative research approach. The qualitative approach is a very useful instrument and helps researchers in answering complex research problem formulations[11]. In this article, the researcher described the data collected through the library research method derived from journals, books, and opinions or articles in online mass media in Indonesia related to the frequency of reporting that contains identity politics. After the data has been collected, analysis and conclusion made. Content analysis as one of the methods of analysis in qualitative research aimed to interpret the meaning of the contents of the text[12]. The results of this study not aimed to make generalizations to all reports in mass media in Indonesia, but only to online media which were used as sources of data and information in this study.

\section{RESULTS AND DISCUSSION}

Media coverage that continues to supply information that filled the public sphere was inseparable from the agenda of the media set itself. The media will continue to emphasize certain events that are considered "important" and "not important" given to the audience until these events are also considered important by the audience with specific aims and objectives of the media[13].

In setting agenda research, there are two basic principles that become assumptions of setting agenda research, namely 1) that what is conveyed by the press or the media to the audience does not reflect the facts, there has been a screening process and issue formation, 2) the mass media only chooses a few issues that considered important. McCombs and Shaw as the originators of the agenda-setting theory concluded that the formation of the public agenda was influenced by the media agenda by proving that there was a strong correlation between the message delivered by the media and the public's response to the message.

Based on search results, Indonesia is the country with the most mass media in the world with 47,000 mass media consisting of 2000 print media, 674 radio, 523 national and local television and the rest are online media[14]. However, not all of the mass media are qualified as media, including journalists who do not have scientific competence in the field of journalism. Meanwhile, according to data from the Ministry of Communication and Information in 2019, the number of online news portals is 43,000 and less than 100 verified online news portals.

Regarding online media reporting containing identity politics material, the researcher took the duration of the news starting from the heated political situation ahead of the Election of the President and Vice President of the Republic of Indonesia in 2019. The rise of the use of identity politics in the momentum of the Presidential Election began with a blasphemy case alleged to Ahok then became a snowball because it was successfully exploited by the elite who became Ahok's political opponents to bring down the popularity and electability of one of the presidential candidates namely Joko Widodo because Ahok was considered part of Joko Widodo's political power. A wave of protests took place in all parts of Indonesia led by community groups labeled with Islam that always linked Ahok and those around Joko Widodo.

The use of identity politics is becoming more and more massive used by political elites amid their inability to popularize welfare issues and other pro-people issues. The use of ethnic and religious issues has always been embedded in campaigns and propaganda that are loaded with identity politics because they are considered capable of gaining the sympathy and support of voters in the future presidential elections. Although there are some parties who identity politics with the aim that social, economic, political and cultural changes occur both partially and interactively[15]. Ethnicity and religious issues used in 
identity politics either directly or indirectly, bring about social change and vice versa[16].

The tight contestation and competition in the presidential election involving two pairs of candidates (Joko Widodo and K.H. Ma'ruf Amin versus Prabowo Subianto and Sandiaga Salahuddin Uno) required the winning teams to find a way out to get the maximum possible vote of the people. Various campaign methods are used, including the most massive one is the use of social media (Facebook, Whatsapp, Instagram, Twitter, YouTube).

Also during the stages of the presidential election, both print and electronic journalists received an abundance of news. Every day, the public space of the Indonesian people is filled with news about the campaign programs of each pair of presidential candidates and mutual propaganda attacking each other mostly carried out by the winning groups of each pair of presidential candidates. The information presented by the mass media and social media in public spaces does not seem to go through the screening stage, because especially in social media, many hoaxes then appear in public spaces.

In addition to print and electronic mass media, in the online mass media, there are also visible political-economic interests of media owners. Like the experience of the Indonesian presidential election in 2014, the media were divided into two camps supporting the presidential candidates.

The media setting agenda is seen in the political momentum, the media that has been politically affiliated to one of the presidential candidate pairs is trying to build public opinion through reporting in the hope that the public will provide political support in the presidential election later. Besides that, political attacks on political opponents are also carried out by the media by raising social, economic and political issues that have the potential to bring down political opponents, including the presentation of information containing identity politics.

Based on agenda-setting theory, there is a highlight on several issues, especially issues concerning identity politics. Promulgation of issues of identity politics that are packaged and appropriately framed is expected to lead to community empathy to form public opinion. This proves the hypothesis of the agenda-setting theory that one's views including public opinion about phenomena that occur in the world are constructed by the media through reporting in the public space including advertisements in the mass media, as stated by McCombs that the media is crucial how does the public describe about this world[17].

\section{CONCLUSION}

Thousands of media in Indonesia should be an important part in efforts to realize a better transition to Indonesia's democracy. Media journalists must be able to filter information which will then be presented in public spaces. The media is not just chasing the number of reader ratings, but more than that that the media is an important instrument in democracy, the media is a "watchdog" in the socioeconomic-political life in a country. Ideally, the media setting agenda should characterize pro-democracy, not be part of the dissemination of information that can break the integrity, unity, and integrity of the nation.

Identity politics, which has recently been raised by the political elite ahead of the presidential election contestation, adds to the problem which has increasingly worsened the quality of democracy in Indonesia. Indonesia as a country with a plural society consisting of different ethnicities, religions, and races, it is very easy for political elites to give birth to identity politics aimed at gaining popularity and public support. The more widespread identity politics, the media look to participate in spreading propaganda and identity politics campaigns.

The media has the main role as mediator which Lippman declared as "the world outside and the pictures in our heads". There is a strong and significant relationship between what is on the mass media agenda and what is scheduled by the public. It is seen that the community will consider an issue, information or news as important as the media consider it to be something important or with the opposite condition.

That agenda-setting theory works in a social reality that can shape understanding and application in society. Theoretically, the agenda-setting unravels the process philosophically and in scientific research, while practically the agenda-setting theory works in the construction of reporting in the mass media.

\section{ACKNOWLEDGMENT}

This research was partially supported by Research and Community Service Institution in Universitas Muhammadiyah Buton. We thank our colleagues who provided insight and expertise that greatly assisted the research. We would also immensely grateful to the organizer of the 1st Borobudur International Symposium of the University of Muhammadiyah Magelang, which has given us the opportunity to present the results of this research, including for their comments on an earlier version of the manuscript.

\section{REFERENCES}

[1] M. Buehler, "Political Reform in Indonesia after Soeharto Harold Crouch . Political Reform in Indonesia after Soeharto . Singapore: Institute of Southeast Asian Studies , 2010 . 390 pp .," vol. 90, no. October, pp. 189-193, 2010.

[2] D. W. Hadi and G. Kasuma, "Propaganda Orde Baru 1966-1980," Verleden, vol. 1, no. 1, pp. 40-50, 2006.

[3] S. Legowo, I. Krisnadi, and H. Sumartono, "Dinamika Politik Rezim Orde Baru Di Indonesia Studi Tentang Kegagalan Konsolidasi Politik Rezim Orde 
[17] M. McCombs, "A Look at Agenda-setting: Past, present and future," Journal. Stud., vol. 6, no. 4, pp. 543-557, 2005.

[4] O. Törnquist, "Introduction Research-based Democracy Promotion: Lessons from Indonesia," PCD J., vol. 2, no. 1, p. 1, 2017.

[5] R. Oktavianti, "Reportase dalam Hegemoni Pemerintah dan Media: Studi Kasus Jurnalis Kepresidenan Era Soeharto dan Joko Widodo," J. Komun. Indones., vol. 5, no. 1, pp. 37-47, 2018.

[6] S. Kasus, P. Islah, K. Golkar, V. Munas, M. Jakarta, and S. Sabrina, "Kredibilitas Komunikator Politik Partai Golkar Dalam Menyelesaikan Konflik Internal Partai," 2017.

[7] K. L. Unsworth and K. S. Fielding, "It's political: How the salience of one's political identity changes climate change beliefs and policy support," Glob. Environ. Chang., vol. 27, no. 1, pp. 131-137, 2014.

[8] S. Y. Chen and O. Urminsky, "The role of causal beliefs in political identity and voting," Cognition, vol. 188, no. May 2018, pp. 27-38, 2019.

[9] P. R. Cristoffanini, "The Representation of "the Others' as Strategies of Symbolic Construction," Arb. Inst. Spr. og Int. Kult., vol. 33, pp. 1-28, 2003.

[10] C. W. Leach, L. M. Brown, and R. E. Worden, "Ethnicity And Identity Politics," Encycl. Violence, Peace, Confl., no. December, pp. 758-768, 2008.

[11] A. B. Hamilton and E. P. Finley, "Reprint of: Qualitative methods in implementation research: An introduction," Psychiatry Res., vol. 283, no. April 2019, p. $112629,2020$.

[12] H. F. Hsieh and S. E. Shannon, "Three approaches to qualitative content analysis," Qual. Health Res., vol. 15, no. 9, pp. 1277-1288, 2005.

[13] E. F. Shaw, "Agenda-setting and mass communication theory," Gazette, vol. 25, no. 2, pp. 96105, 1979.

[14] W. Agustina, "Terungkap, Indonesia Punya Media Massa Terbanyak di Dunia," Tempo. 2018.

[15] A. A. N. Juhana Nasrudin, "Politik Identitas dan Representasi Politik (Studi Kasus pada Pilkada DKI Periode 2018-2022)," Hanifiya J. Stud. Agama-Agama, vol. 1, no. 1, pp. 34-47, 2018.

[16] G. Sukamto, "Politik Identitas (Suatu Kajian Awal dalam Kerangka dan Interaksi 'Lokalitas' dan "Globalisasi)," J. Sej. dan Budaya, vol. 2, no. 2, pp. 923, 2010. 